University of Nebraska - Lincoln

DigitalCommons@University of Nebraska - Lincoln

USDA National Wildlife Research Center - Staff Publications
U.S. Department of Agriculture: Animal and Plant Health Inspection Service

2011

\title{
Vulture Flight Behavior and Implications for Aircraft Safety
}

Michael L. Avery

USDA/APHIS/WS National Wildlife Research Center, michael.I.avery@aphis.usda.gov

John S. Humphrey

USDA/APHIS/WS National Wildlife Research Center, John.S.Humphrey@aphis.usda.gov

Trey S. Daughtery

USDA Wildlife Services

Justin W. Fischer

USDA/APHIS/WS National Wildlife Research Center, Justin.w.fischer@aphis.usda.gov

Michael P. Milleson

USDA/APHIS/WS National Wildlife Research Center

See next page for additional authors

Follow this and additional works at: https://digitalcommons.unl.edu/icwdm_usdanwrc

Part of the Environmental Sciences Commons, and the Life Sciences Commons

Avery, Michael L.; Humphrey, John S.; Daughtery, Trey S.; Fischer, Justin W.; Milleson, Michael P.; Tillman, Eric A.; Bruce, William E.; and Walter, W. David, "Vulture Flight Behavior and Implications for Aircraft Safety" (2011). USDA National Wildlife Research Center - Staff Publications. 1010.

https://digitalcommons.unl.edu/icwdm_usdanwrc/1010

This Article is brought to you for free and open access by the U.S. Department of Agriculture: Animal and Plant Health Inspection Service at DigitalCommons@University of Nebraska - Lincoln. It has been accepted for inclusion in USDA National Wildlife Research Center - Staff Publications by an authorized administrator of DigitalCommons@University of Nebraska - Lincoln. 


\section{Authors}

Michael L. Avery, John S. Humphrey, Trey S. Daughtery, Justin W. Fischer, Michael P. Milleson, Eric A. Tillman, William E. Bruce, and W. David Walter 


\title{
Vulture Flight Behavior and Implications for Aircraft Safety
}

\author{
MICHAEL L. AVERY, ${ }^{\mathbf{1}}$ United States Department of Agriculture, Wildlife Services, National Wildlife Research Center, Florida Field Station, \\ 2820 East University Avenue, Gainesville, FL 32641, USA \\ JOHN S. HUMPHREY, United States Department of Agriculture, Wildlife Services, National Wildlife Research Center, Florida Field Station, \\ 2820 East University Avenue, Gainesville, FL 32641, USA \\ TREY S. DAUGHTERY, United States Department of Agriculture, Wildlife Services, Marine Corps Air Station, Beaufort, SC 29904, USA \\ JUSTIN W. FISCHER, United States Department of Agriculture, Wildlife Services, National Wildlife Research Center, Fort Collins, CO 80521, USA \\ MICHAEL P. MILLESON, United States Department of Agriculture, Wildlife Services, National Wildlife Research Center, Florida Field Station, \\ 2820 East University Avenue, Gainesville, FL 32641, USA \\ ERIC A. TILLMAN, United States Department of Agriculture, Wildlife Services, National Wildlife Research Center, Florida Field Station, \\ 2820 East University Avenue, Gainesville, FL 32641, USA \\ WILLIAM E. BRUCE, United States Department of Agriculture, Wildlife Services, National Wildlife Research Center, Florida Field Station, \\ 2820 East University Avenue, Gainesville, FL 32641, USA
}

W. DAVID WALTER, United States Department of Agriculture, Wildife Services, National Wildlife Research Center, Fort Collins, CO 80521, USA

\begin{abstract}
Growing vulture populations represent increasing hazards to civil and military aircraft. To assess vulture flight behavior and activity patterns at the Marine Corps Air Station in Beaufort, South Carolina, we equipped 11 black vultures (Coragyps atratus) and 11 turkey vultures (Cathartes aura) with solarpowered Global Positioning System (GPS) satellite transmitters during a 2-year study (1 Oct 2006-30 Sep 2008). Turkey vultures had larger seasonal home ranges than did black vultures, and 2 turkey vultures made round-trips to Florida. Black vultures consistently spent less time in flight (8.4\%) than did turkey vultures (18.9\%), and black vultures flew at higher altitudes than did turkey vultures in all seasons except summer when altitudinal distributions (above ground level) did not differ. Although we recorded maximum altitudes of 1,578 m for black vultures and 1,378 for turkey vultures, most flights were low altitude. A matrix of vulture flight altitude versus time of day revealed that $>60 \%$ of vulture flight activity occurred from $4 \mathrm{hr}$ to $9 \mathrm{hr}$ after sunrise at altitudes below $200 \mathrm{~m}$. Continuation of aggressive harassment coupled with flexible training schedules to avoid times and altitudes of high vulture activity will decrease hazards to aircraft posed by these birds. (C) 2011 The Wildlife Society.
\end{abstract}

KEY WORDS aviation hazard, bird-aircraft strike, black vulture, Cathartes aura, Coragyps atratus, flight behavior, satellite telemetry, turkey vulture.

Black vultures (Coragyps atratus) and turkey vultures (Cathartes aura) represent substantial hazards to aircraft. According to the United States Air Force (USAF) bird strike database, black vultures and turkey vultures rank number 3 and number 4, respectively, in total cost of bird strikes to them (USAF 2009). Combined, turkey vultures and black vultures have been responsible for more civil aircraft strikes involving human injury than any other bird species except the Canada goose (Branta canadensis; Dolbeer et al. 2009). Vultures are large (approx. $2 \mathrm{~kg}$ ), have limited capacity to make evasive flight maneuvers, and often fly in groups. Each of these factors contributes to their hazard potential to aircraft.

Results from the annual Breeding Bird Survey indicate that populations of both species have increased markedly in recent years in North America (Avery 2004, Sauer et al. 2008), and

Received: 1 October 2010; Accepted: 13 February 2011;

Published: 26 July 2011

${ }^{1}$ E-mail: michael.l.avery@aphis.usda.gov since 1980 the black vulture population index in South Carolina has increased at an annual rate of 9.9\% (Sauer et al. 2008). During this same time period, the turkey vulture population index increased $11.9 \%$ annually. In South Carolina, black vultures and many turkey vultures are resident year-round. The strong population trends of these species nationwide, and the range expansion of the black vulture to the north and east (Buckley 1999), suggest that vulture-related problems will increase in the foreseeable future.

The area around Marine Corps Air Station in Beaufort, South Carolina (MCAS-Beaufort) harbors a healthy vulture population, which creates dangerous bird-strike situations for pilots. Since 2006, four vulture-aircraft strikes have occurred at this site (Table 1). Vultures are a major threat to aviation safety at MCAS-Beaufort and understanding their flight behavior and activity patterns will contribute substantially to lessening risks to pilots. Although others have investigated various aspects of vulture flight activity 
Table 1. Vulture-aircraft strikes recorded at Marine Corps Air Station, Beaufort, South Carolina, 2006-2010. Altitude is presented as m above ground level. Details are not available for the incident on 4 August 2006.

\begin{tabular}{lccccc}
\hline Species & Date & Time & Hour after local sunrise & Altitude (m) & Flight stage \\
\hline Turkey vulture & 04 Aug 2006 & & & & \\
Turkey vulture & 16 Nov 2006 & 1515 & 8.4 & 458 & Approach \\
Turkey vulture & 14 Apr 2009 & 1030 & 4.2 & 122 & Takeoff \\
Black vulture & 16 Sep 2010 & 1200 & 7.0 & Takeoff \\
\hline
\end{tabular}

on a small scale, there has been no comprehensive assessment of vulture movements and activity patterns in the vicinity of a military or civilian airport (Rubin 1999, Arrington 2003, DeVault et al. 2005).

Our objectives were to use Global Positioning System (GPS) satellite telemetry to quantify vulture flight activity and infer actions that may reduce the risk of vulture-aircraft interactions.

\section{STUDY AREA}

The study site $\left(32.4735^{\circ} \mathrm{N}, 80.7194^{\circ} \mathrm{W}\right)$ is approximately 3 m elevation in the low-country salt marsh ecosystem region of coastal South Carolina. The air station was approximately $5 \mathrm{~km}$ from downtown Beaufort. Surrounding upland habitat was mostly conifer and mixed conifer-hardwood forest.

\section{METHODS}

\section{Satellite Telemetry}

Beginning in September 2006, we captured black and turkey vultures on MCAS-Beaufort using a baited walk-in trap $(9.3 \mathrm{~m} \times 3.1 \mathrm{~m} \times 1.8 \mathrm{~m}$; Humphrey et al. 2000). Each bird received a uniquely coded white cattle ear-tag (Allflex, Inc., Dallas, TX) attached to the patagium of the right wing (Wallace et al. 1980, Sweeney et al. 1985). We recorded body mass and assigned vultures to either juvenile or adult age classes based on the amount of feathering and wrinkling on the head. We attached 70-g solar-powered GPS satellite transmitters (PTT-100; Microwave Telemetry, Inc., Columbia, MD) to 16 vultures with a Teflon tape backpack harness (Humphrey et al. 2000). Initially, the 16 transmitters were apportioned equally between black and turkey vultures. We released captured birds at the trap site. Subsequently, several birds died and we redeployed their transmitters on new birds to bring the total sample size to 22 vultures.

The GPS transmitters recorded latitude-longitude, altitude above ground level (resolution $\pm 22 \mathrm{~m}$ ), speed, and direction on the hour from dawn to dusk. Daily start and end times were adjusted seasonally according to local sunrise-sunset. We periodically downloaded the recorded data into a spreadsheet database for further manipulation and analyses. We adjusted all records to express them in terms of hours after local sunrise. Hour 0 was the hour immediately before sunrise, hour 1 included the first hour immediately after sunrise, and so on. We analyzed telemetry data to assess the flight altitude and daily activity patterns of birds relative to local sunrise. As appropriate, we made comparisons between species and among seasons: fall (Oct-Dec), winter (Jan-Mar), spring (Apr-Jun), summer (Jul-Sep). We captured and processed vultures according to procedures specified in study protocol QA-1394, reviewed and approved by the Institutional Animal Care and Use Committee of the National Wildlife Research Center. We attached patagial tags and satellite transmitters as authorized under Federal Bird Banding Permit 06859.

\section{Vulture Flight Behavior}

We defined a bird to be in flight if the speed recorded by the transmitter was $>0 \mathrm{~km} / \mathrm{hr}$. In each season, we recorded the number of all in-flight locations for each bird according to hour after sunrise. We then divided by the total number of locations for the individual during the season to estimate the proportion of time it was in flight. We calculated an hourly mean and standard error for each species. We also calculated seasonal means to assess the annual activity pattern of each species.

For each bird, we sorted the in-flight locations (i.e., speed $>0 \mathrm{~km} / \mathrm{hr}$ ) and examined patterns seasonally throughout the year and hourly within each season. For both species, the recorded altitudes were greatly skewed toward lower altitudes and did not conform to normal distributions, so we opted for nonparametric statistical comparisons using the KruskalWallis test (Sokal and Rohlf 1969).

To address autocorrelation in estimating size of home range from GPS technology, we subsampled locations for each vulture prior to home range estimations. Because $>100$ locations are considered an adequate sample size to estimate size of home range (Kernohan et al. 2001), we randomly selected 120 locations per month (3-month seasons $=360$ locations per season or approx. 4 locations per day) to estimate home range. Subsamples included both roosting and flying locations.

We calculated 95\% utilization distributions to estimate seasonal home ranges for each vulture using $\geq 1,440$ locations (i.e., 360 locations/season) collected for each vulture during the study. We used the fixed-kernel method to estimate $95 \%$ fixed-kernel home range (hereafter home range) because it considered density of locations and was considered most accurate at determining outer boundary areas (i.e., 95\% isopleths) compared with adaptive kernel (Worton 1995). We determined space use and the amount of smoothing using the least-squares cross-validation $\left(h_{\mathrm{LSCV}}\right)$ method with the default parameter in the Home Range Extension of ArcView 3.2 (ArcView; Environmental Systems Research Institute, Redlands, CA). We tested home ranges for 
normality, $\log$ transformed them, and compared them using two-way analysis of variance with least squares means to test the difference between species during different seasons.

\section{Vulture Occurrence Matrix}

To summarize and focus the information on vulture flight activity and altitude, we developed a matrix representing the relative frequency with which vultures (both species combined) occurred within a given altitude interval at a given hour. We created 11 altitude intervals in 100-m increments. We expressed time as hours after local sunrise, from 0 to 14 . Within each cell of this $11 \times 15$ altitude-time matrix, we calculated relative percentage of vulture occurrence by dividing the number of vulture locations in that cell by the total number of in-flight records during the study and multiplying by 100 . Then, we assigned each cell to one of 6 relative percentage occurrence categories: $X \geq 5 \%, 5 \%>X \geq 1 \%$, $1 \%>X \geq 0.5 \%, 0.5 \%>X \geq 0.1 \%, 0.1 \%>X>0$, and $\mathrm{X}=0$.

\section{RESULTS}

\section{Satellite Telemetry}

Because we were able to recover and reuse some transmitters, we equipped 22 vultures with satellite transmitters during the 2 -yr study (Table 2). Eight birds were alive and transmitting at the end of the study, on 30 September 2008. Four vultures remained alive for the entire study, but 4 turkey vultures equipped early in the study were monitored less than 2 months each. Even so, these 4 turkey vultures contributed substantially to our findings by demonstrating the array of fatal hazards (traffic, shooting, electrocution) that exists for vultures and by documenting the tendency for turkey vultures to roam widely. During the $2-\mathrm{yr}$ study period, the transmitters logged 106,554 locations from the 22 birds (Table 2).

\section{Vulture Flight Behavior}

Both vulture species were most active in the winter (JanMar) and least active in the summer (Jul-Sep). Across all months, black vultures were in flight $8.4 \%(\mathrm{SE}=0.4)$ of daylight hours compared to $18.9 \%(\mathrm{SE}=0.8)$ for turkey vultures (Fig. 1). On an hourly basis, turkey vultures were in flight consistently more often than black vultures (Fig. 2). Regardless of season, by $3 \mathrm{hr}$ after sunrise, about $10 \%$ of the turkey vulture locations were in flight. Turkey vulture flight activity peaked in the middle of the day and then gradually declined. Black vultures tended to lag turkey vultures by approximately $1 \mathrm{hr}$ in commencing their daily flight activity, and they rarely exceeded turkey vultures in the proportion of in-flight locations for any hour during the day. Even when the proportion of black vulture in-flight locations was greatest, it was approximately half the level exhibited by turkey vultures.

In each species, locations were skewed toward lower altitudes. Of the 3,992 black vulture in-flight locations, 48\% were $<100 \mathrm{~m}$ in altitude (Fig. 3). Among turkey vultures, $60 \%$ of 9,622 in-flight records were $<100 \mathrm{~m}$. In every $100-\mathrm{m}$ interval above $200 \mathrm{~m}$, the proportion of the black vulture locations exceeded that of turkey vultures (Fig. 3). The maximum black vulture altitude was $1,578 \mathrm{~m}$ while the highest turkey vulture recorded was $1,378 \mathrm{~m}$.

During winter $\quad\left(H_{1}=114.2 ; \quad P<0.001\right), \quad$ spring $\left(H_{1}=205.8 ; \quad P<0.001\right), \quad$ and fall $\quad\left(H_{1}=41.9\right.$; $P<0.001)$, the distribution of flight altitudes of black vultures differed from that of turkey vultures (Fig. 4). During summer (Jul-Sep), however, the distribution of flight altitudes did not differ between species $\left(H_{1}=0 ; P=0.967\right)$. The median flight altitude for black vultures was highest during April-June (157.5 m; Fig. 4). The rest of the year the

Table 2. Identities, number of telemetry locations, period during which birds were monitored, and fates of black vultures (BL) and turkey vultures (TU) equipped with Global Positioning System satellite transmitters at Marine Corps Air Station, Beaufort, South Carolina, 1 October 2006-30 September 2008.

\begin{tabular}{lcccc}
\hline Vulture & Age & Mass $\mathbf{( k g )}$ & Locations & Period of activity $^{\text {Fate }^{\mathbf{a}}}$ \\
\hline BL47 & Ad & 2.12 & 6,844 & 1 Oct 2006-30 Sep 2008 \\
BL48 & Ad & 2.17 & 6,347 & 1 Oct 2006-14 Apr 2008 \\
BL49 & Juv & 2.28 & 3,272 & 1 Oct 2006-20 Jun 2007 \\
BL49A & Ad & 2.06 & 5,158 & 20 Sep 2007-30 Sep 2008 \\
BL50 & Ad & 2.44 & 1,798 & 1 Oct 2006-28 Feb 2007 \\
BL50A & Ad & 2.23 & 6,422 & 5 Apr 2007-6 Sep 2008 \\
BL53A & - & 2.28 & 8,227 & 13 Sep 2007-30 Sep 2008 \\
BL57 & Ad & 2.40 & 8,502 & 5 Oct 2006-30 Sep 2008 \\
BL58 & Juv & 1.94 & 3,387 & 5 Oct 2006-30 Jun 2007 \\
BL61 & Juv & 1.97 & 5,391 & 1 Nov 2006-28 Nov 2007 \\
BL62 & Juv & 1.99 & 1,889 & 1 Nov 2006-9 Apr 2007 \\
TU51 & Ad & 1.76 & 8,617 & 1 Oct 2006-30 Sep 2008 \\
TU52 & Ad & 1.81 & 10,570 & 1 Oct 2006-30 Sep 2008 \\
TU53 & Ad & 1.89 & 318 & 1 Oct 2006-26 Oct 2006 \\
TU54 & Ad & 1.81 & 6,537 & 1 Oct 2006-7 Apr 2008 \\
TU55 & Juv & 1.76 & 236 & 1 Oct 2006-2 Nov 2006 \\
TU55A & Ad & 1.89 & 2,008 & T Apr 2007-30 Aug 2007 \\
TU56 & Ad & 1.80 & 5,231 & 1 Oct 2006-15 Nov 2007 \\
TU59 & Juv & 2.17 & 221 & 26 Oct 2006-15 Nov 2006 \\
TU59A & Ad & 1.90 & 6,970 & 5 Apr 2007-30 Sep 2008 \\
TU60 & Juv & 1.93 & 1,197 & 26 Oct 2006-18 Nov 2006 \\
TU60A & Ad & 1.93 & 7,437 & 5 Apr 2007-30 Sep 2008 \\
\hline
\end{tabular}

${ }^{\text {a }}$ TC—-transmission ceased, fate of bird unknown; DU—dead, unknown cause; DT—dead, traffic; DS—dead, shot; DE—dead, electrocuted. 


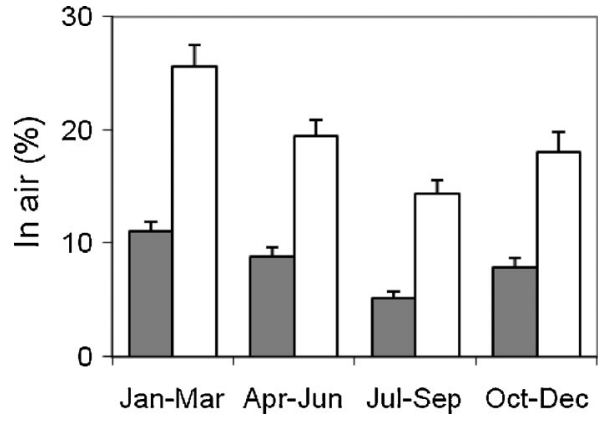

Figure 1. Percentage of time black vultures (solid bars) and turkey vultures (open bars) were in flight during daytime by season, 1 October 2006-30 September 2008, in the vicinity of Beaufort, South Carolina. We equipped vultures with satellite transmitters, which provided hourly information from dawn to dusk on the birds' location, altitude, and speed. We assumed that birds with recorded speed $>0 \mathrm{~km} / \mathrm{hr}$ were in flight.

median was approximately $100 \mathrm{~m}$. Median turkey vulture flight altitude was greatest $(109 \mathrm{~m})$ during summer and lowest $(64 \mathrm{~m})$ in winter (Fig. 4).

Through the first $4 \mathrm{hr}$ of daylight, most vulture flight activity occurred below $50 \mathrm{~m}$, regardless of the season (Fig. 5). During the middle hours of the day, black vultures consistently flew at $150 \mathrm{~m}$ or higher, whereas turkey vultures stayed mostly in the 50-100 m range. For turkey vultures,
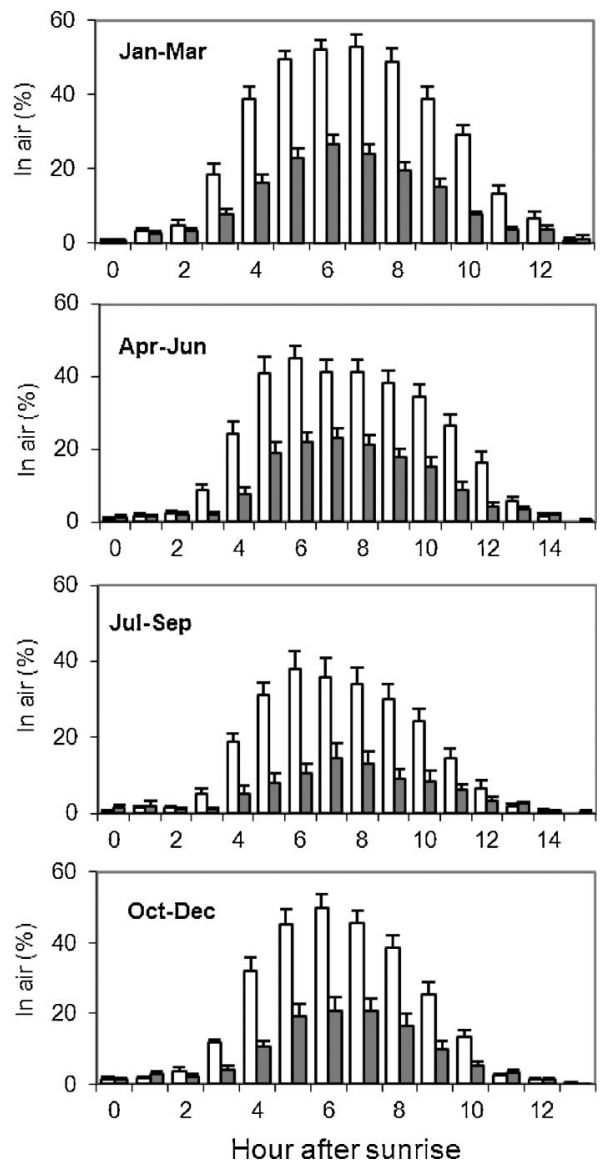

Figure 2. Percentage of time satellite transmitter-equipped black vultures (solid bars) and turkey vultures (open bars) were in flight during daytime, in the vicinity of Beaufort, South Carolina, 1 October 2006-30 September 2008 .

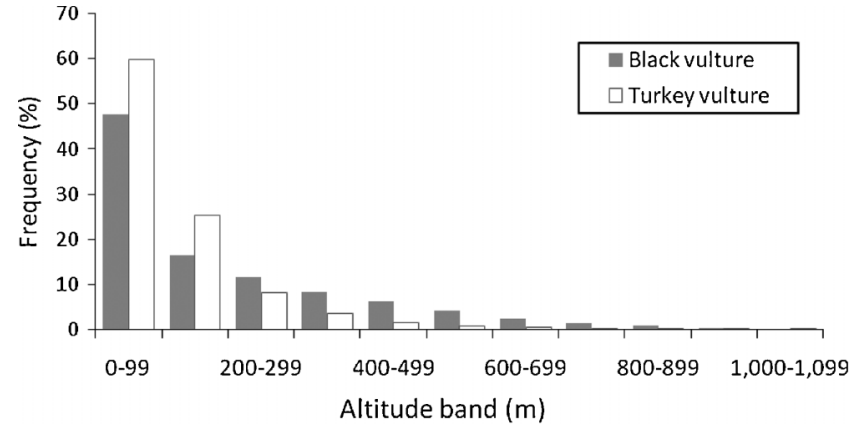

Figure 3. Distribution of black vultures (solid bars, 3,981 locations) and turkey vultures (open bars, 9,663 locations) according to altitude above ground level, 1 October 2006-30 September 2008, in the vicinity of Beaufort, South Carolina. Not shown are 11 black vulture and 2 turkey vulture altitude records $>1,100 \mathrm{~m}$.

the exception was summer, when the median flight altitude was 100-150 m during the middle of the day (Fig. 5).

There was considerable variation among individuals in the estimated size of seasonal home ranges (Table 3 ). We found no interaction by species and season $\left(F_{3}, \quad 56=1.09\right.$, $P=0.360)$ for home range of vultures and no difference by season $\left(F_{3,56}=0.27, P=0.847\right.$; Table 3$)$. Across all seasons, turkey vultures had larger home ranges than black vultures $\left(F_{1,56}=12.54, P<0.001\right)$. Two turkey vultures traveled to Florida and back. Each of these birds went south in February and arrived in central Florida 2 and 5 weeks later, respectively. One returned to Beaufort in mid-April, but the other spent several weeks on the Florida-Georgia border and arrived back in Beaufort in late June. One other turkey vulture flew to south Florida where it was shot less than 1 month into the study.

\section{Vulture Occurrence Matrix}

Across the entire study, vulture flight activity was greatest 4$9 \mathrm{hr}$ after sunrise within $100 \mathrm{~m}$ of the ground (Fig. 6). These 6 time-altitude cells accounted for $41 \%$ of the total vulture in-flight telemetry locations. Over $92 \%$ of all vulture inflight locations were included within time-altitude cells with relative occurrence $\geq 0.5 \%$ (Fig. 6).

\section{DISCUSSION}

Unlike previous studies, our satellite transmitters provided a detailed account of vulture movements with data collection

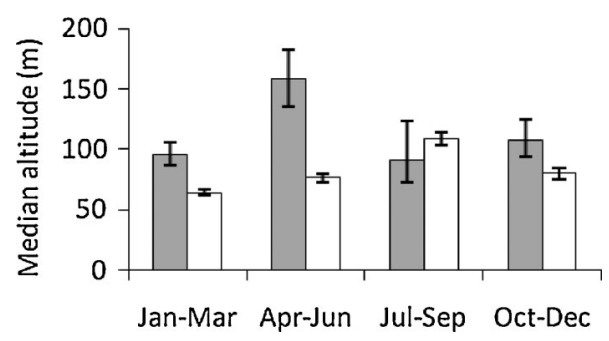

Figure 4. Median altitudes above ground level of satellite transmitterequipped black vultures (solid bars) and turkey vultures (open bars) during winter (Jan-Mar), spring (Apr-Jun), summer (Jul-Sep), and fall (Oct-Dec) in the vicinity of Beaufort, South Carolina, 1 October 2006-30 September 2008. The capped vertical bars denote the $95 \%$ confidence interval. 

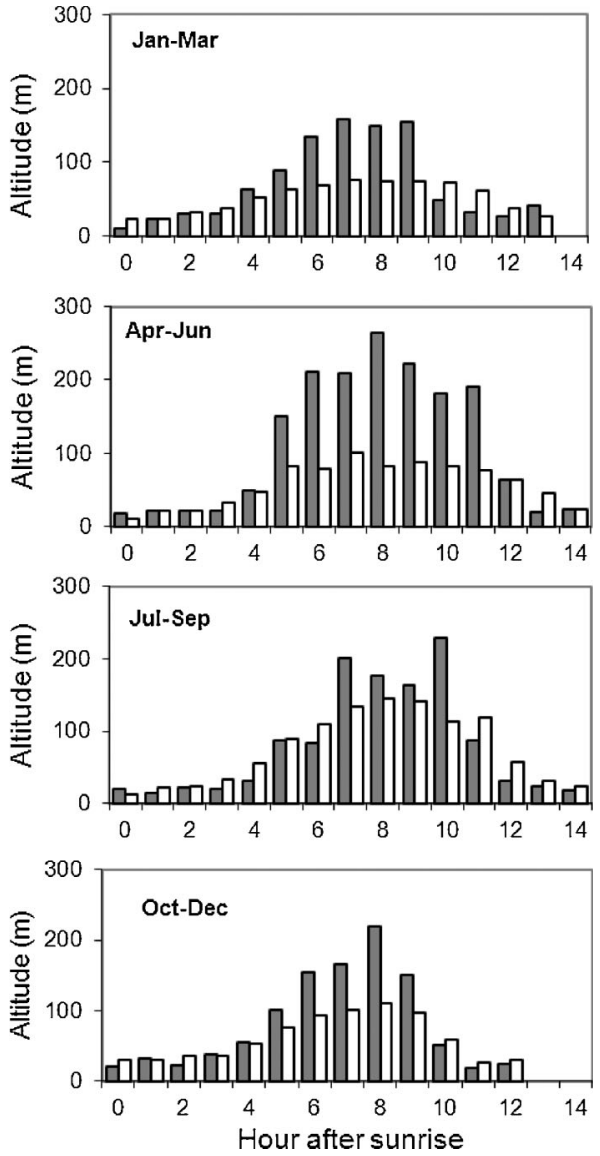

Figure 5. Median altitudes above ground level of black (solid bars) and turkey (open bars) vultures, throughout the day, during each season in the vicinity of Beaufort, South Carolina, during 1 October 2006-30 September 2008.

efforts not dependent on weather (DeVault et al. 2004), road systems in study area (Coleman and Fraser 1989, Buckley 1996), or direct observations (Arrington 2003). The information we derived from over 100,000 GPS locations illuminates several aspects of vulture behavior described but not fully quantified previously. In particular, the differences in flight time and altitude between black vultures and turkey vultures are now more clearly defined through direct, contemporaneous comparisons of the 2 species. Collectively, the earlier studies each contribute to an overall portrait of black vulture and turkey vulture flight behavior that is now explicitly quantified, at least for this region of the country, by our detailed findings using GPS satellite telemetry.
Throughout the day, greater proportions of turkey vultures were aloft than black vultures. For both species, flight activity was maximal during the middle of the day. The distribution of altitudes for each species was heavily skewed toward lower altitudes, but turkey vultures flew closer to the ground than black vultures. Although the details vary seasonally, the pattern of relative differences between the species was consistent throughout the year. Others have noted that black vultures generally fly higher, have smaller home ranges, and spend less time in the air than turkey vultures (Coleman and Fraser 1989, Buckley 1996, DeVault et al. 2004). The difference in flight altitudes between the 2 vulture species has been explained by black vultures watching the behavior of turkey vultures and other birds to locate food more efficiently (Stewart 1978, Buckley 1996). The consistently reduced flight activity of black vultures relative to turkey vultures is perhaps partially due to the advantage gained by the black vultures' higher flight altitudes. Alternatively, an increase in black vulture foraging efficiency could be related to information exchange at their roost site (Rabenold 1987). Black vultures are highly social, and these social interactions create feeding advantages at carcasses (Rabenold 1986, Parker et al. 1995). Thus, to meet their foraging needs, black vultures might have to be in the air much less often than turkey vultures which do not exhibit similar social behaviors.

Foraging requirements could also account for the seasonal variation exhibited by each species in the amount of time in flight (Fig. 1) and home range size (Table 3). Colder weather likely imposes the need for a greater foraging effort than in warmer months in both species. Concurrently, a shorter day length during colder months reduces the amount of area a foraging vulture can cover. Thus, during winter, vultures on average are in the air more frequently and within a smaller home range than during summer months. Furthermore, in areas of sympatry, there are fundamental differences in how the 2 species use the landscape, whether it is mostly forested (DeVault et al. 2004), agricultural (Coleman and Fraser 1989), or coastal lowlands (this study). Turkey vultures prefer to feed on small carcasses (Kirk and Mossman 1998) and regardless of season, these resources are dispersed and unpredictable, thereby requiring search efforts more wide-ranging and time-consuming than needed by black vultures (Coleman and Fraser 1989). Analysis of the food habits of this vulture population would help elucidate this and other aspects of the species' foraging behavior.

Table 3. Seasonal home range estimates $\left(\mathrm{km}^{2}\right)$ for black and turkey vultures trapped at Marine Corps Air Station, Beaufort, South Carolina and equipped with Global Positioning System satellite transmitters, 1 October 2006 to 30 September 2008.

\begin{tabular}{lcccc}
\hline & Winter & Spring & Summer & Fall \\
\hline Black vultures & & & & \\
$\quad$ Median & 11 & 68 & 143 & \\
Range & $1-3,985$ & $8-4,754$ & $2-3,106$ & \\
$N$ & 11 & 10 & $7-260$ & 11 \\
Turkey vultures & 68 & 110 & 551 & 1207 \\
$\quad$ Median & $36-25,056$ & $37-7,619$ & $26-2,860$ & $109-12,884$ \\
Range & 6 & 7 & 6 & 6 \\
$N$ & & &
\end{tabular}






Figure 6. The likelihood of occurrence within a given time-alitude block by local vultures (both species combined) in the vicinity of Beaufort, South Carolina, 1 October 2006-30 September 2008. Time is expressed as hour after local sunrise and altitude above ground is denoted by $100-\mathrm{m}$ intervals. Red indicates vulture occurrence within the time-altitude block $\geq 5 \%$ of the time. For orange cells, vulture occurrence was $<5 \%$ but $\geq 1 \%$. Yellow cells denote vulture use $<1 \%$, but $\geq 0.5 \%$ of the time. In green cells, vultures were recorded $<0.5 \%$, but $\geq 0.1 \%$ of the time. Vulture occurrence in blue cells was $>0$ but $<0.1 \%$. Gray cells indicate $0 \%$ vulture occurrence. The cells within the heavy black outline accounted for over $92 \%$ of the in-flight locations we recorded. The documented vulture-aircraft strikes at Marine Corps Air Station-Beaufort are indicated by stars.

The vulture activity information we gained is directly applicable to improving conditions for aircraft safety. Analyses of vulture-aircraft strike records revealed that 162 of $367(44 \%)$ occurred within $150 \mathrm{~m}$ of the ground (Dolbeer 2006). In our study, $70.4 \%$ of the vultures aloft were within the $0-150 \mathrm{~m}$ altitude range. Turkey vultures constituted 7,350 of 9,616 (76.4\%) of these low-level flights. The 3 vulture air strikes at MCAS-Beaufort for which time and altitude data are available each took place within a timealtitude block with a relatively high frequency of vulture occurrence (Fig. 6). Also, 3 of the 4 vulture air strikes involved turkey vultures (Table 1), which is consistent with our results where turkey vulture in-flight locations $(9,622)$ outnumbered those of black vultures $(3,922) 2.4$ to 1 . Furthermore, 2 of the 3 vulture strikes for which details are available occurred during take-off, which reinforces the concern that low-level flights, including take-off and landing, are most at risk for encountering vultures (Table 1; Dolbeer 2006).

Our detailed information of vulture flight behavior captured by GPS technology represents a unique data set that furthers our understanding of various facets of vulture ecology and management. Beyond what we presented, examples include refinement of vulture population estimates (Runge et al. 2009), assessment of vulture detectability relative to avian radar (Beason et al. 2010), more accurate vulture home range estimates (J. W. Fischer, National Wildlife Research Center, unpublished report), 3-dimensional vulture flight analyses for aircraft safety (W. D. Walter, National Wildlife Research Center, unpublished report), vulture roost site selection, and landscape resource utilization.

\section{MANAGEMENT IMPLICATIONS}

The relative risk of encountering a vulture in airspace depends largely on the number of birds aloft at a given altitude. Vulture flight activity varies seasonally and with time of day, among other factors. Although it is not possible to determine absolute degrees of risk, it might be possible to lower risk by avoiding times and altitudes most heavily used by vultures near airfields. Incorporating data derived from GPS satellite telemetry, the occurrence matrix (Fig. 6) provides managers and pilots with quantitative information on the relative probabilities of encountering vultures throughout the day at different altitudes. Used in concert with other methods (Avery et al. 2002, Teague 2002), the occurrence matrix is a management tool that can assist in improving aircraft safety. This concept is readily applicable to other civilian and military facilities where vultures occur.

\section{ACKNOWLEDGMENTS}

Funding for this study was through contract N62467-06RP-00202 between the United States Department of Agriculture (USDA) Wildlife Services and the Southern Division, Naval Facilities Engineering Command. We thank N. Myers, South Carolina State Director, USDA/Wildlife Services, for conceiving this project.

\section{LITERATURE CITED}

Arrington, D. P. 2003. Flight characteristics of non-migrating and migrating populations of turkey vultures. Dissertation, Purdue University, West Lafayette, Indiana, USA.

Avery, M. L. 2004. Trends in North American vulture populations. Vertebrate Pest Conference 21:116-121.

Avery, M. L., J. S. Humphrey, E. A. Tillman, K. O. Phares, and J. E. Hatcher. 2002. Dispersing vulture roosts on communication towers. Journal of Raptor Research 36:45-50.

Beason, R. C., J. S. Humphrey, N. E. Myers, and M. L. Avery. 2010. Synchronous monitoring of vulture movements with satellite telemetry and avian radar. Journal of Zoology 282:157-162.

Buckley, N. J. 1996. Food finding and the influence of information, local enhancement, and communal roosting on foraging success of North American vultures. Auk 113:473-488.

Buckley, N. J. 1999. Black vulture (Coragyps atratus). Number 411 in A. Poole and F. Gill, editors. The birds of North America. The Academy of Natural Sciences, Philadelphia, Pennsylvania, and The American Ornithologists' Union, Washington, D.C., USA.

Coleman, J. S., and J. D. Fraser. 1989. Habitat use and home ranges of black and turkey vultures. Journal of Wildlife Management 53:782-792.

DeVault, T. L., B. D. Reinhart, I. L. Brisbin, Jr., and O. E. Rhodes. Jr. 2004. Home ranges of sympatric black and turkey vultures in South Carolina. Condor 106:706-711.

DeVault, T. L., B. D. Reinhart, I. L. Brisbin, Jr., and O. E. Rhodes. Jr. 2005. Flight behavior of black and turkey vultures: implications for reducing bird-aircraft collisions. Journal of Wildlife Management 69:601-608.

Dolbeer, R. A. 2006. Height distribution of birds recorded by collisions with civil aircraft. Journal of Wildlife Management 70:1345-1350.

Dolbeer, R. A., S. E. Wright, J. Weller, and M. J. Begier. 2009. Wildlife strikes to civil aircraft in the United States, 1990-2008. U. S. Department of Transportation, Federal Aviation Administration, Serial Report No. 15. Washington, D.C., USA.

Humphrey, J. S., M. L. Avery, and A. P. McGrane. 2000. Evaluating relocation as a vulture management tool in north Florida. Vertebrate Pest Conference 19:49-53.

Kernohan, B. J., R. A. Gitzen, and J. J. Millspaugh. 2001. Analysis of animal space use and movements. Pages 125-166 in J. J. Millspaugh and J. M. Marzluff, editors. Radio tracking and animal populations. Academic Press, San Diego, California, USA. 
Kirk, D. A., and M. J. Mossman. 1998. Turkey Vulture (Cathartes aura). Number 339 in A. Poole and F. Gill, editors. The birds of North America. The Academy of Natural Sciences, Philadelphia, Pennsylvania, and The American Ornithologists' Union, Washington, D.C., USA.

Parker, P. G., T. A. Waite, and M. D. Decker. 1995. Kinship and association in communally roosting black vultures. Animal Behaviour 49:395401.

Rabenold, P. P. 1986. Family associations in communally roosting black vultures. Auk 103:32-41.

Rabenold, P. P. 1987. Recruitment to food in black vultures: evidence for following from communal roosts. Animal Behaviour 35:1775-1785.

Rubin, D. J. 1999. Using satellite telemetry to determine seasonal movement and weather influences on flight altitude of turkey vultures to reduce strike hazards to military aircraft. Thesis, New Mexico State University, Las Cruces, USA.

Runge, M. C., J. R. Sauer, M. L. Avery, B. F. Blackwell, and M. D. Koneff. 2009. Assessing allowable take of migratory birds. Journal of Wildlife Management 73:556-565.

Sauer, J. R., J. E. Hines, and J. Fallon. 2008. The North American Breeding Bird Survey, Results and Analysis 1966-2007. Version 5.15.2008. USGS Patuxent Wildlife Research Center, Laurel, Maryland, USA.
Sokal, R. R., and F. J. Rohlf. 1969. Biometry. W. H. Freeman and Company, San Francisco, California, USA.

Stewart, P. A. 1978. Behavioral interactions and niche separation in black and turkey vultures. Living Bird 17:79-84.

Sweeney, T. M., J. D. Fraser, and J. S. Coleman. 1985. Further evaluation of marking methods for black and turkey vultures. Journal of Field Ornithology 56:251-257.

Teague, D. D. 2002. Vulture roost dispersal-improving air safety at Eglin AFB. Flying Safety 58:22-25.

USAF Safety Center. 2009. Top 50 USAF wildlife strikes by cost. $<$ http://www.afsc.af.mil/shared/media/document/AFD-080130-040.pdf $>$. Accessed 7 Jun 2011.

Wallace, M. P., P. G. Parker, and S. A. Temple. 1980. An evaluation of patagial markers for cathartid vultures. Journal of Field Ornithology 51:309-314.

Worton, B. J. 1995. Using Monte Carlo simulation to evaluate kernelbased home range estimators. Journal of Wildlife Management 59:794800 .

Associate Editor: Bruce Thompson. 